\title{
高对称度光源的同步辐射 $\mathbf{X}$ 射线同轴相祄成像
}

\author{
黎刚 ${ }^{1 * \dagger}$, 张杰 ${ }^{1 \dagger}$, 易栖如 ${ }^{1 \dagger}$, 王艳萍 ${ }^{1}$, 陈雨 ${ }^{1}$, 贾全杰 ${ }^{1}$, 姜晓明 $1,2^{* \dagger}$ \\ 1. 中国科学院高能物理研究所, 北京 100049 ; \\ 2. 中国科学院北京综合研究中心, 北京 101407 \\ * 联系人, E-mail: lig@ihep.ac.cn; jiangxm@ihep.ac.cn \\ $\dagger$ 同等贡献
}

2016-10-21 收稿, 2016-12-02 修回, 2016-12-02 接受, 2017-06-08 网络版发表 中国科学院科研装备研制项目(YZ201211)、中国科学院北京综合研究中心创新课题(2014-01)、中国科学院北京综合研究中心自主部署课 题(Y5Z003)和国家自然科学基金(11675208, 11305200)资助

摘要全球现有的同步辐射光源中，电子束团在垂直于运动方向的截面上其水平尺寸和垂直尺寸的差异都较 大，即同步辐射X射线(SRX)源的尺寸在水平和垂直两方向上有较大差异(二者的比值为光源的对称度，与 1 的差别 越大，则对称度越差）。这使得利用同步辐射 $\mathrm{X}$ 射线开展同轴相衬成像实验时，水平和垂直两个方向上入射 $\mathrm{X}$ 射线 的点扩展函数相差较大, 造成两个方向上空间分辨率有很大差别, 这种差异还会造成两个方向上相位补度水平的 明显差别, 从而严重影响同轴相位衬度成像的质量. 本文通过在北京同步辐射装置(BSRF)成像线站(4W1A)束线 上加入白光光阑直接限制光源对样品的点扩展函数的方法, 获得了一个对称度大大提高的同步辐射X射线源(光 源对称度从2.7提高到接近 1 ), 并开展了模型样品(聚酰胺细丝)的同轴相位祄度成像实验. 使 $4 \mathrm{~W} 1 \mathrm{~A}$ 的光源对称度 从 2.7 提高到 1 , 虽然会使总通量约减小为原来的 0.0005 , 但通量密度只减小到原来的 0.22 . 总通量的减小由光斑尺 寸的减小和通量密度的减小共同决定, 由于高分辨率同轴成像需要的光斑尺寸很小, 因此本方法对高分辨率同轴 成像的不利影响仅限于通量密度的减小. 同时, 研究结果表明, 通过关小水平光阑尺寸, 把对成像有贡献的水平 方向光源尺寸从 $1.23 \mathrm{~mm}$ 减小到约 $0.35 \mathrm{~mm}$, 使模型样品成像的最大相位衬度从 0.057 提高到了 0.35 , 即通过关小光 阑提高光源的对称度, 使同轴相衬成像的密度灵敏度提高了5 倍. 光源对称度的提高, 使空间分辨率和相位衬度这 两方面在水平方向和垂直方向达到相同的水平，从而极大改善了BSRF 4W1A线站SRX同轴相位补度成像的质量. 我们分析了成像质量提升的原因, 并讨论了未来进一步改进的方向.

关键词 $\mathrm{X}$ 射线同轴相位衬度成像, 光源对称度, 衬度, 空间分辨率, 同步辐射, 点扩展函数

$\mathrm{X}$ 射线在物质中的折射率可表示为: $n=1-\delta-\mathrm{i} \delta$. 其中 $\delta$ 与相位变化相关, $\beta$ 与吸收相关. 在 $15 \sim 100 \mathrm{keV}$ 的范围内, 大部分轻元素的 $\delta$ 比 $\beta$ 大 $2 \sim 3$ 个数量级. 因 此, 轻元素为主的样品引起的硬X射线的相位改变远 高于其对硬X射线的吸收, 因而相位改变带来的成像 衬度远高于吸收带来的衬度. 生物软组织大部分由 $\mathrm{C}, \mathrm{H}, \mathrm{O}$ 等轻元素构成, 吸收衬度很弱, 适合采用相
位衬度进行成像. 而高能硬X射线的利用将有助于在 获得较好衬度的同时, 大幅度降低生物体所受的辐 射剂量.

相位衬度成像是采用某种方法把样品对波函数 相位的调制转换成透射光强度的变化记录下来. 同 步辐射X射线具有亮度高、能谱宽、相干性好等突出 优点，在生物体相位衬度成像中具有独特优势. 目前

引用格式: 黎刚, 张杰, 易栖如, 等. 高对称度光源的同步辐射 $\mathrm{X}$ 射线同轴相衬成像. 科学通报, 2017, 62: 2544-2552

Li G, Zhang J, Yi Q R, et al. Synchrotron radiation X-ray in-line phase-contrast imaging with highly symmetric source (in Chinese). Chin Sci Bull, 2017, 62: 2544-2552, doi: 10.1360/N972016-00905 
主要的相位衬度成像方法包括同轴相衬成像 ${ }^{[1]}$ 、衍射 增强成像 ${ }^{[2]}$ 、光栅剪切成像 ${ }^{[3]}$ 等. 其中同轴相衬成像 利用具有一定空间相干性的X射线穿过样品后在自 由空间的传播来获得相位衬度，实验设置简单，在同 步辐射光源上应用得最广泛. 但是该方法的成像效 果在许多同步辐射成像束线上并不理想, 特别在追 求更高空间分辨率的相位衬度成像时, 相位衬度的 成像质量(相位衬度水平)总是让人不太满意, 严重限 制了这种方法的生物医学应用. 以前的工作中 ${ }^{[4 \sim 11]}$ 一 般把这种高空间分辨下相位衬度成像质量较差的原 因归结为人射 $X$ 射线的点扩展函数较大和探测器的 空间分辨率差等因素, 并探讨了这两个因素对同轴 $\mathrm{X}$ 射线成像质量的影响.

在本课题组以前的研究中 ${ }^{[12]}$, 探讨了光源对称 度对同步辐射相位衬度成像质量的影响. 光源对称 度定义为同步辐射 $\mathrm{X}$ 射线源水平方向尺寸和垂直方 向尺寸的比值, 该值越接近于1则光源的对称度越高. 研究发现, 同轴相衬成像时X射线源较低的对称度会 引起不同方向上点扩展函数随物像距离变化的较大 差别, 造成空间分辨率和相位衬度增强幅度的不一 致, 需要在某个折衷的物像距离处才能获得质量较 好的同轴相衬图像.

目前, 世界上同步辐射X射线(Synchrotron Radiation X-ray, SRX)成像束线的光源对称度差异较大, 见表1. 可以发现, 多级Wiggler作X射线源时的光源
对称度最低，比值均大于 10 ; 弯铁或波荡器作 $X$ 射线 源的对称度较好，但一般也分布在3 8之间，只有意 大利SYRMEP束线的光源对称度达到 1.7 的较好水平. 为了研究X射线源对称度的变化和同轴相位衬度成 像质量之间的关系，本论文通过在北京同步辐射装 置(Beijing Synchrotron Radiation Facility, BSRF)成像 线站 $(4 \mathrm{~W} 1 \mathrm{~A})$ 光束线上加人小尺寸限光光阑, 获得了 一个对称度大大提高的 SRX光源, 从而使本课题组 能第一次从实验上研究光源对称度的变化对 SRX同 轴相位衬度成像质量的影响. 研究结果表明, 光源对 称度的提高极大改善了BSRF $4 \mathrm{~W} 1 \mathrm{~A}$ 线站SRX同轴相 位衬度成像的质量. 最后分析了成像质量提升的原 因以及进一步改进的方向.

\section{1 实验}

\section{1 实验几何}

实验采用 $\mathrm{BSRF}$ 的 $4 \mathrm{~W} 1$ 单周期电磁扭摆器为光 源，磁极间隙 $66 \mathrm{~mm}$ ，周期长度 $1.392 \mathrm{~m}$, 峰值磁场强 度 $1.8 \mathrm{~T}$, 临界能量 $5.8 \mathrm{keV}$. 光源尺寸的半高宽为 $1.23 \mathrm{~mm}$ (水平) $\times 0.46 \mathrm{~mm}$ (垂直), 光源不对称度约为 2.7. 通过 $42 \mathrm{~m}$ 长的 $4 \mathrm{~W} 1 \mathrm{~A}$ 束线 ${ }^{[12]}$ 把同步辐射白光引 人到实验棚屋中, 经 $\operatorname{Si}(111)$ 双晶单色器单色化后照 射在样品上. 实验采用能量为 $13 \mathrm{keV}$ 的单色 $\mathrm{X}$ 射线.

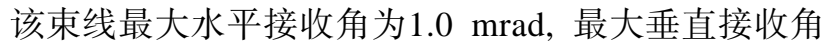

\section{表 1 世界部分同步辐射硬X射线相祄成像束线的参数 ${ }^{a)}$}

Table 1 Parameters of some synchrotron radiation hard X-ray phase contrast imaging beamlines in the world ${ }^{\text {a) }}$

\begin{tabular}{|c|c|c|c|c|c|}
\hline 束线和光源 & 光源类型 & $\begin{array}{c}\text { 光源尺寸 }{ }^{\mathrm{b})} \\
(H \mu \mathrm{m} \times V \mu \mathrm{m})\end{array}$ & 光源对称度 & 物源距离(m) & $\begin{array}{c}\text { 点扩展函数@物像距1 m } \\
(H \mu \mathrm{m} \times V \mu \mathrm{m})\end{array}$ \\
\hline CLS-BMIT-ID & S-MW & $441 \times 16.6$ & 26.6 & 55 & $8 \times 0.3$ \\
\hline AS-IMBL & S-MW & $361 \times 19$ & 19 & 136 & $2.6 \times 0.14$ \\
\hline SSRF-13W1 & MW & $408 \times 23$ & 17.7 & 32 & $12.75 \times 0.78$ \\
\hline PF-14C & S-SW & $1160 \times 72$ & 16 & 35 & $33 \times 2.0$ \\
\hline SPring-8BL20B2 & $\mathrm{BM}$ & $114 \times 14$ & 8.1 & 215 & $0.5 \times 0.07$ \\
\hline CLS-BMIT-BM & $\mathrm{BM}$ & $173 \times 30.8$ & 5.6 & 23 & $7.5 \times 1.3$ \\
\hline APS 2BM-B & $\mathrm{BM}$ & $230 \times 50$ & 4.6 & 50 & $4.6 \times 1$ \\
\hline ESRF-ID19 & $\mathrm{U}$ & $120 \times 30$ & 4.0 & 145 & $0.83 \times 0.2$ \\
\hline SLS-TOMCAT & S-BM & $53 \times 16$ & 3.3 & 20 & $2.56 \times 0.8$ \\
\hline BSRF-4W1A & SW & $524 \times 195^{\mathrm{c})}$ & 2.7 & 42 & $12.5 \times 4.6$ \\
\hline ELETTRA-SYRMEP & $\mathrm{BM}$ & $135 \times 80$ & 1.7 & 23 & $5.9 \times 3.5$ \\
\hline
\end{tabular}

a) S-MW：超导多级扭摆器, MW: 多级扭摆器, BM: 弯铁, SW：单极扭摆器, S-BM：超导弯铁, S-SW：超导单极扭摆器, U: 波荡 器. 各光源参数来源于http://www.lightsources.org/, 光源对称度及点扩展函数根据光源尺寸和物源距离计算得出; b) 表中光源尺寸为电子 束团尺寸的sigma值, 光源的半高宽是sigma值的 2.35 倍; c) 数据根据实验当天弯铁的束流实测尺寸以及 $4 \mathrm{~W} 1$ 的磁铁参数推算得到 
为 $0.3 \mathrm{mrad}$, 真空度为 $10^{-7} \mathrm{torr}$, 两端由铍窗隔绝, 末 端封有铝窗用来保护铍窗. 实验几何如图1所示, 在 距离光源 $17 \mathrm{~m}$ 处有一个白光光阑, 通过调节这个白 光光阑的水平和垂直尺寸, 可以改变光源的点扩展 函数以及光源的对称度.

实验所用探测器是本课题组自行研制的高分辨 率间接探测器. 该探测器用单晶闪炼体薄膜把人射 $\mathrm{X}$ 射线的图像高效率、高分辨地转化成可见光图像, 通 过显微耦合系统把闪㷧晶体薄膜上的图像放大并传 递到可见光面探测器上, 实现X射线图像的高分辨率 探测. 实验时采用 $4.6 \mu \mathrm{m}$ 厚的钲掺杂钝镓石榴石 (Gadolinium Gallium Garnet: Terbium, GGG:Tb)闪炇 晶体薄膜, 耦合系统的物镜为 $20 \times 0.45 \mathrm{NA}$, 中间变倍 镜 $2 \times$, 可见光面探测器的像素为 $13 \mu \mathrm{m}$. 探测器的等 效像素尺寸为 $0.325 \mu \mathrm{m}$, 空间分辨率为 $0.65 \mu \mathrm{m}$, 有 效视野宽度约为 $0.3 \mathrm{~mm}$. 探测器放置在双晶单色器 后约 $1 \mathrm{~m}$ 的地方, 即距光源点 $43 \mathrm{~m}$ 处, 可以实现物像
距离在0 1 m范围内变化.

实验样品为聚酰胺细丝组成的网格, 单根细丝 的直径为 $50 \mu \mathrm{m}$. 实验时沿光路移动样品, 分别在物 像距离为 $4,10,16,36,100,200$ 和 $300 \mathrm{~mm}$ 处对样品进 行同轴相衬成像. 为了比较光源点的对称度对相位 衬度成像质量的影响, 分别在两种情况下进行了上 述成像实验:

(1) 白光光阑完全打开, 此时对样品上任一点的 光强有贡献的光源尺寸约为 $1.23 \mathrm{~mm}$ (水平) $\times 0.46$ $\mathrm{mm}$ (垂直), 即光源对称度约为 2.7 ; 曝光时间 $40 \mathrm{~s}$, 探测器的电子增益为 20 倍, 平均光强为 33000 .

(2) 采用减小白光光阑水平和垂直方向尺寸的 方法来提高成像系统光源的对称度, 原理如图2所示. 把距离光源 $17 \mathrm{~m}$ 的白光光阑水平方向关至约为 210 $\mu \mathrm{m}$ 宽时, 对样品上任一点有贡献的光源水平尺寸变 为: $S_{x} \approx 210 \mu \mathrm{m} \times(17+25+1) / 26 \approx 350 \mu \mathrm{m}$. 此时把垂直 方向的白光光阑也关小到约 $210 \mu \mathrm{m}$. 通过这种调节,

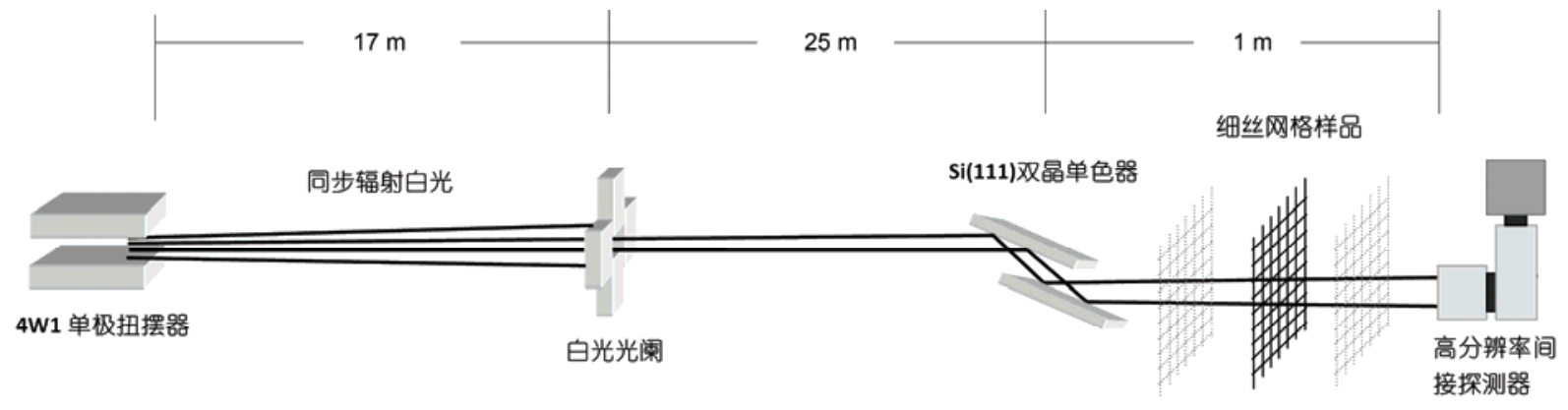

图 1 BSRF 4W1A束线开展X射线同轴相衬成像实验几何示意图

Figure 1 Sketch of X-ray in-line phase contrast imaging setup at BSRF 4W1A beamline

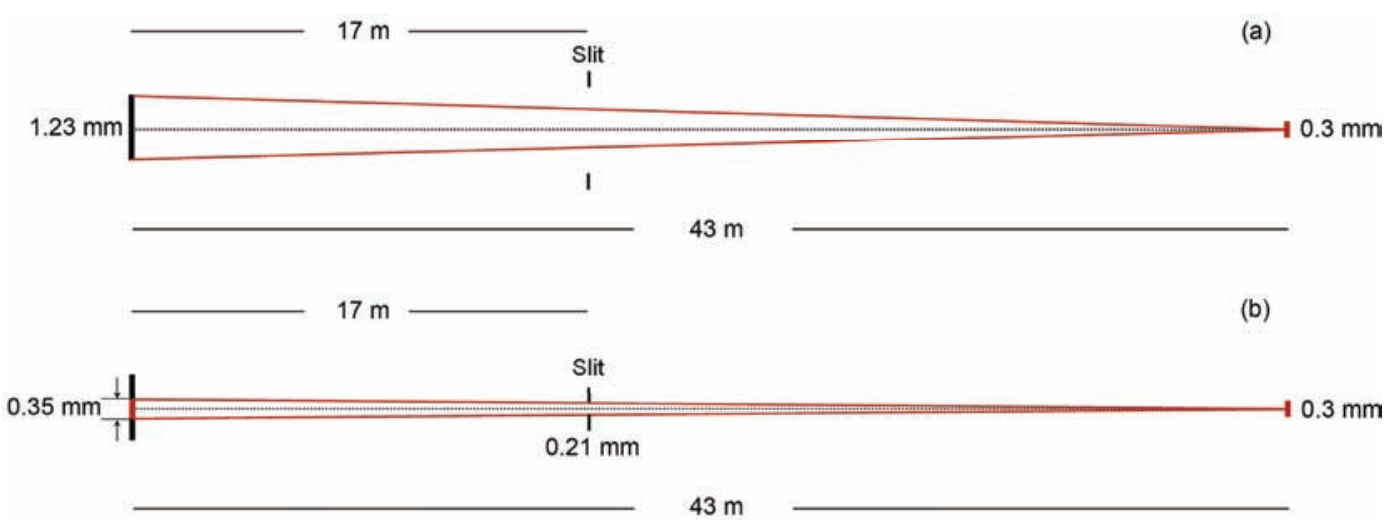

图 2 (网络版彩色)在水平方向上样品、白光光阑和光源尺寸几何关系的示意图. (a) 白光光阑全开时探测器上任一像素的光强来自 $1.23 \mathrm{~mm}$ 光 源上各个点的贡献; (b) 白光光阑关小至 $0.21 \mathrm{~mm}$ 时, 探测器上任一像素的光强来自 $0.35 \mathrm{~mm}$ 光源上各个点的贡献

Figure 2 (Color online) Geometrical sketch of sample, white beam slit and source size in horizontal direction. (a) White beam slit is open, the X-ray intensity of a certain detector pixel is contributed by $1.23 \mathrm{~mm}$ source; (b) white beam slit is closed to $0.21 \mathrm{~mm}$, and the X-ray intensity of a certain detector pixel is contributed by $0.35 \mathrm{~mm}$ source 
光源的对称度提高到了约 1.0. 这时单张图像的曝光 时间增加为 $60 \mathrm{~s}$, 探测器的电子增益为 20 倍, 平均光 强为 11000 .

\section{2 实验结果}

(i ) 白光光阑完全打开时. 此时, 光源的尺寸 为 $1.23 \mathrm{~mm}$ (水平) $\times 0.46 \mathrm{~mm}$ (垂直), 光源对称度约为 2.7. 当物像距离很小时 (10 mm以下), 衬度主要来源 于吸收衬度, 在 $X$ 射线能量为 $13 \mathrm{keV}$ 的条件下, $50 \mu \mathrm{m}$ 直径的聚酰胺细丝网格吸收衬度很小, 在实验图像 中基本不可见. 当物像距离增加到 $16 \mathrm{~mm}$ 时, 水平和 坚直方向放置的细丝网格边缘均出现可观察的相位 衬度(图3(a)). 随着物像距离进一步增大, 直至 300 $\mathrm{mm}$, 水平放置的细丝的相位衬度逐步增强; 而垂直 放置的细丝相位衬度变化不大, 而且随着距离的增 加边界逐渐变得模糊, 如图3(c)所示.

为了更清楚地呈现这种差异, 沿图3(a)中白色线 段所示的位置对所有距离的图像作截线, 结果如

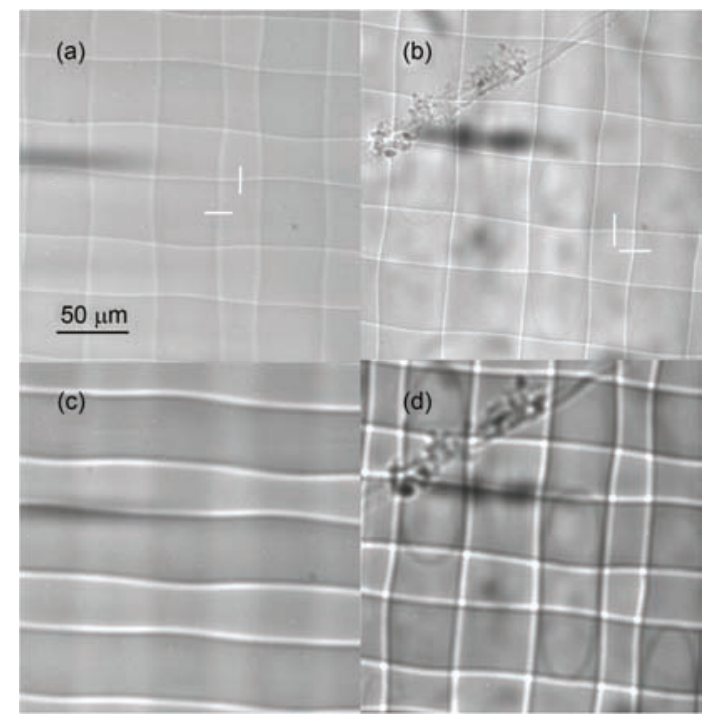

图 3 细丝网格在不同对称度光源下的同轴相衬成像结果举例. (a), (c) 白光光阑完全打开光源对称度低时的结果; (b), (d) 白光光阑关 小到 $210 \mu \mathrm{m} \times 210 \mu \mathrm{m}$ 光源对称度高时的结果. (a)和(b)的物像距离为 $16 \mathrm{~mm},(\mathrm{c})$ 和 $(\mathrm{d})$ 的物像距离为 $300 \mathrm{~mm}$. 在 $(\mathrm{d})$ 中可以看到在细丝内部 有椭圆型的气泡. (b)和(d)左上角的干扰结构来自光路

Figure 3 Some experiment results of in-line phase contrast imaging to polyamide fiber under different source symmetry conditions. (a), (c) are obtained from white beam slit completely opening and low source symmetry, (b), (d) correspond to $210 \mu \mathrm{m} \times 210 \mu \mathrm{m}$ white beam slit size and high source symmetry. The distance of object to detector (DOD) related to (a) and (b) is $16 \mathrm{~mm}$, DOD related to (c) and (d) is $300 \mathrm{~mm}$. Oval air bubbles in fiber can be seen from (d), some irregular structures on top of (b) and (d) stem from beamline setup 图4(a)，(b)所示．从图中可以看出，在白光光阑完全 打开的条件下，垂直方向具有典型的同轴相衬成像 边缘衬度的增强, 随着物像距离的增加, 细丝边缘光 强增强的幅度越来越大(图4(b))，形成强烈反差的是 水平方向边缘衬度的增强效应很弱(图4(a)及其局部 放大图)

(ii) 把距离光源 $17 \mathrm{~m}$ 的白光光阑关小到约 210 $\mu \mathrm{m} \times 210 \mu \mathrm{m}$. 此时, 光源的尺寸约为 $350 \mu \mathrm{m} \times 350 \mu \mathrm{m}$, 光源的对称度为 1.0. 提高光源对称性后的同轴相衬 成像结果如图 3(b), (d) 所示. 物像距离较近时 (16 $\mathrm{mm})$ (图3(b)), 细丝网格的图像在水平和坚直两个方 向均具有可观察到边界增强效应. 物像距离较远时 $(300 \mathrm{~mm})$ (图3(d)), 细丝网格的图像在水平和坚直两 个方向的边界增强效应进一步明显增强. 沿图3(b)中 白色线段所示的位置对此条件下所有距离的图像作 截线的结果如图4(c), (d)所示. 从图中可以看出, 在 白光光阑关小到接近相等的条件下, 水平方向具有 与垂直方向相近的典型的同轴相衬成像边缘衬度的 增强。

\section{2 数据分析}

\section{1 光阑大小对通量和通量密度的影响}

关小白光光阑会引起 X射线光斑尺寸和总通量 的明显下降. $4 \mathrm{~W} 1$ 束线的接收角分别为 $1 \mathrm{mrad} \times 0.3$ $\mathrm{mrad}$, 距离光源 $17 \mathrm{~m}$ 处白光光阑上的光斑面积为 17 $\mathrm{mm} \times 5.1 \mathrm{~mm}$, 实验中白光光阑的大小为 $0.21 \mathrm{~mm} \times$ $0.21 \mathrm{~mm}$. 用白光光阑关小后的通光面积和其上光斑 面积的比可以粗略估计关小白光光阑引起的总通量 下降，二者的比值为 $5.2 \times 10^{-4}$. 即关小光阑使光斑的 总通量下降了约 2000 倍. 但照射到样品上的X射线通 量密度的下降远没有这么大. 由图3(a)，(b)可知，白 光光阑关小前后探测器单个像素上的光强约为 33000 和 $11000 ，$ 曝光时间为 40 和 $60 \mathrm{~s}$ ，关小白光光阑前后 光强的比值约为 $4.5: 1$.

其中的原因是 BSRF $4 \mathrm{~W} 1$ 光源在水平方向的半

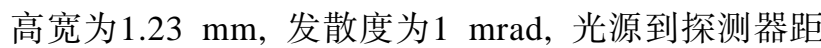
离为 $43 \mathrm{~m}$. 在关小白光光阑前, 光源上任一点在探测 器所在平面形成的光斑水平尺寸为 $43 \mathrm{~mm}$. 此时, 探 测器上任一点的光强来自于 $1.23 \mathrm{~mm}$ 宽的水平光源; 关小白光光阑后, 对探测器上每个像素光强有贡献 的光源尺寸减小为 $0.35 \mathrm{~mm}$ (图2), 即关小水平光阑 

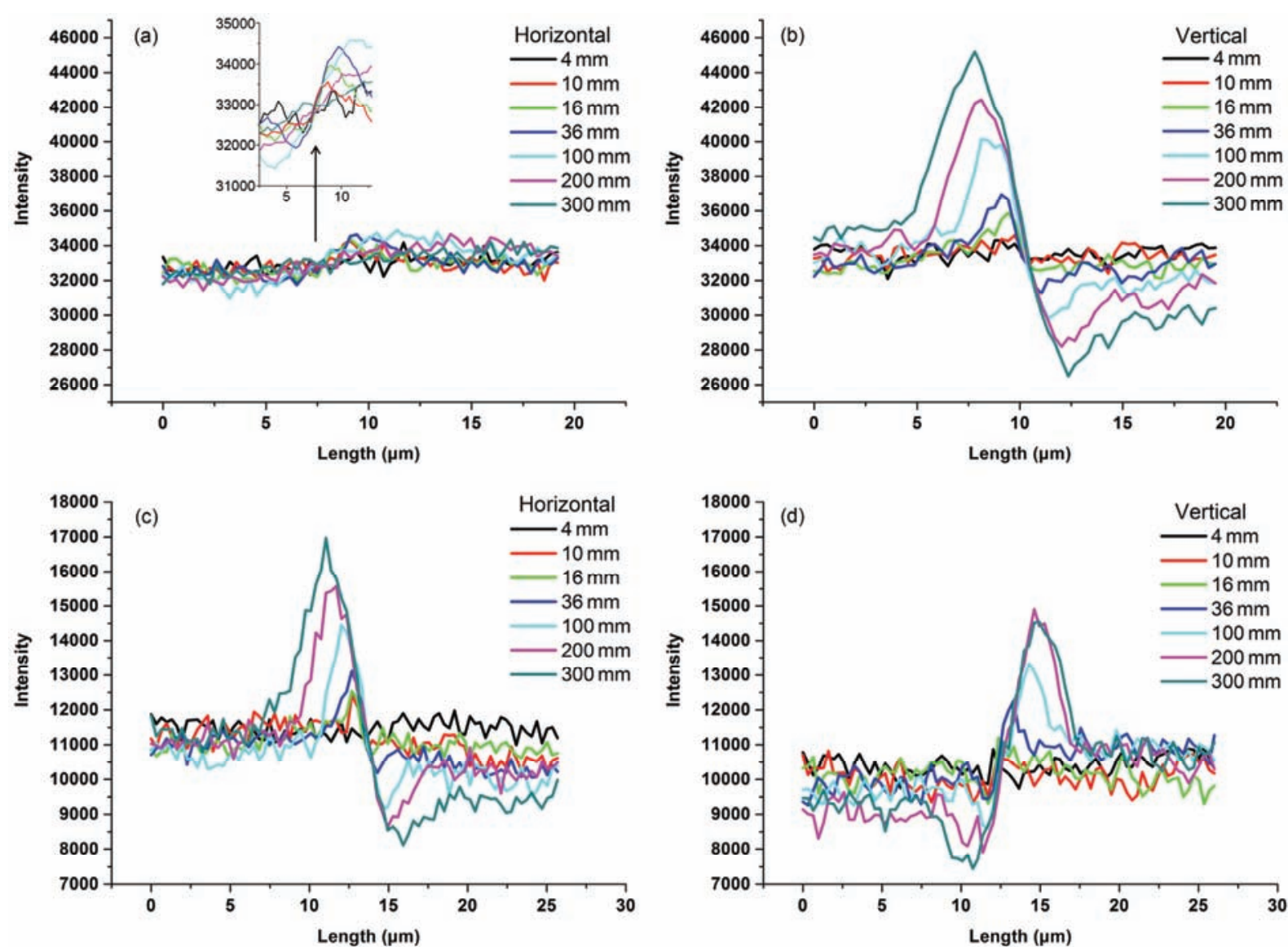

图 4 两种光源对称度下细丝边界处的光强截线随物像距离变化的实验结果. 截线的位置在图 3(a), (b)中用白色线段标示. (a), (b) 白光光阑完 全打开光源，对称度低的条件下水平方向和垂直方向的截线; (c), (d) 白光光阑关小到约 $210 \mu \mathrm{m} \times 210 \mu \mathrm{m}$ 光源对称度高的条件下水平方向和垂 直方向的截线. 不同颜色代表了不同的物像距离, 分别为 4, 10, 16, 36, 100, 200 和 $300 \mathrm{~mm}$. 图(a)中的局部细节图对原数据进行了适当的平滑 处理

Figure 4 Intensity curves depicted along a pixel line crossing the fiber edge at different DODs under two kinds of source symmetry. The pixel lines are marked by white lines on Figure 3(a) and (b). (a) and (b) respectively shows curves in horizontal and vertical direction under white beam slit completely opening and low source symmetry conditions. (c) and (d) shows curves in horizontal and vertical direction under $210 \mu \mathrm{m} \times 210 \mu \mathrm{m}$ white beam slit size and high source symmetry conditions. DOD, indicated by different colors, is respective 4, 10, 16, 36, 100, $200 \mathrm{and} 300 \mathrm{~mm}$. The curves showed in detailed image in (a) is moderately smoothed

前后的光强比为 $3.5: 1$. 同样, 在垂直方向, 光源尺 寸的半高宽是 $0.46 \mathrm{~mm}$, 把垂直方向光阑关小到 0.21 $\mathrm{mm}$ 后的光强比是 $1.3: 1$. 因此, 关小白光光阑前后总 的光强变化为 $4.55: 1$, 与实验得到的关小白光光阑前 后的强度比十分接近.

采用关小白光光阑的方法提高光源的对称度, 虽然会使总通量有 3 个量级的下降, 但主要来自于光 斑尺寸的减小, 通量密度的下降只有几倍. 这对于高 分辨成像的光强影响较小, 但却可以大大提高系统 同轴相衬成像的质量.

实验中可以在白光光阑前利用聚焦元件对人射 $\mathrm{X}$ 射线进行一定的聚焦来提高通过光阑的通量, 亦可
以在白光光阑后放置聚焦元件, 虽然不能提高总通 量, 但是可以提高照射到样品上的X射线通量密度. 由于聚焦元件也会对等效光源发散度产生一定的影 响, 因此需要仔细考虑以免聚焦元件造成等效光源 发散度变差. 如果条件允许, 将白光光阑靠近光源点 也能提高通量.

\section{2 光源对称度对相位衬度的影响}

在本实验中, 光源水平和垂直方向的发散度都 比较大, 此时光源尺寸是影响光源点扩展函数的主 要因素, 光源尺寸越大, 点扩展函数越差, 光源尺寸 越小, 点扩展函数越好. 
根据图4中的截线和衬度的定义 ${ }^{[13]}$ :

$$
\text { Contrast }=\frac{I_{\max }-I_{\text {min }}}{I_{\text {max }}+I_{\text {min }}},
$$

计算了在光源不同对称度下每个物像距离的同一细 丝固定边缘位置在水平和垂直两个方向的衬度, 结 果如图 5所示. 可以明显地看到, 当白光光阑正常打 开时, 在光源对称度较低、光源水平方向点扩展函数 较差的条件下, 细丝边缘水平方向的衬度远低于垂 直方向的衬度. 水平方向在物像距离为 $100 \mathrm{~mm}$ 附近 达到衬度的最大值 0.057 , 随着物像距离增大而逐渐 下降. 而垂直方向的衬度则一直随物像距离增加而 增大, 直到本次测量的最远距离 $300 \mathrm{~mm}$ 处衬度增大 至0.261. 即不同的光源点扩展函数会对样品的相位 衬度产生巨大影响。

与此形成鲜明对比, 在白光光阑均关小到约 210 $\mu \mathrm{m}$, 光源对称度大大提高的条件下, 细丝边缘水平 方向的衬度和垂直方向的衬度随着物像距离的增加 而非常一致地增加, 当物像距离增加至 $300 \mathrm{~mm}$ 时, 这两个方向的衬度分别增大到 0.35 和 0.32 .

上述结果表明, 通过调节水平光阑大小 (即光源 的水平点扩展函数), 可以很容易地调节水平方向上 聚酰胺细丝边界的最大相位衬度从约 0.057 , 增加到 约 0.35 , 增大了 5 倍, 同时还获得了高对称度光源的 成像.

其实, 这一点不难理解. 光源的点扩展函数越 小, 人射X射线的空间相干性越好, 同轴相位衬度成 像获得的衬度增强就越大; 反之, 光源的点扩展函数
大，人射X射线的空间相干性就越差，同轴相衬成像 能够获得的衬度增强越小.

\section{3 光源对称度对成像质量的影响}

从图4的4幅曲线图中可以观察到, 细丝边界光 强截线的宽度随物像距离的增大而增大. 以图4中光 强截线峰值与谷值的平均作为基线，将光强截线分 为亮区和暗区，通过统计细丝边界处光强截线亮区 半高全宽(Full Width at Half Maximum, FWHM，相对 于基线强度)的像素数目可以测量其宽度. FWHM和 物体到探测器的距离之间的关系如图6(a)所示. 图中 的数据点来自对图 4(a) (c)3幅图光强截线中亮区的 FWHM的测量. 直线由最小二乘法拟合得到. 图6(a) 表明，光源点扩展函数大则细丝边界光强截线的 FWHM随着物像距离的增加快速地单调增大，这个 现象将对图像的空间分辨率产生重要影响。以瑞利 (Rayleigh)判据作为标准对不同FWHM条件下的图像 分辨率做了一个初步估计. 按照瑞利判据，两个亮斑 相互靠近到一定程度，在各自峰位强度间会产生鞍 点, 若鞍点强度超过了峰强的 $73.5 \%$ 则认为这两个亮 斑已不能分辨，此时两个亮斑峰位间的距离为该条 件下的空间分辨率. 若两个亮斑完全一致且对称分 布，则峰位左右两侧强度为峰强 $36.75 \%$ 的两点间距 离可以代表该条件下的空间分辨率. 因此根据图 4, 分析了光强截线亮区相对基线强度为(峰强-基线) $\times$ $36.75 \%$ 的两点间距离，以此反映各条件下的空间分 辨率，得到了与FWHM相似的结果，如图6(b)所示,
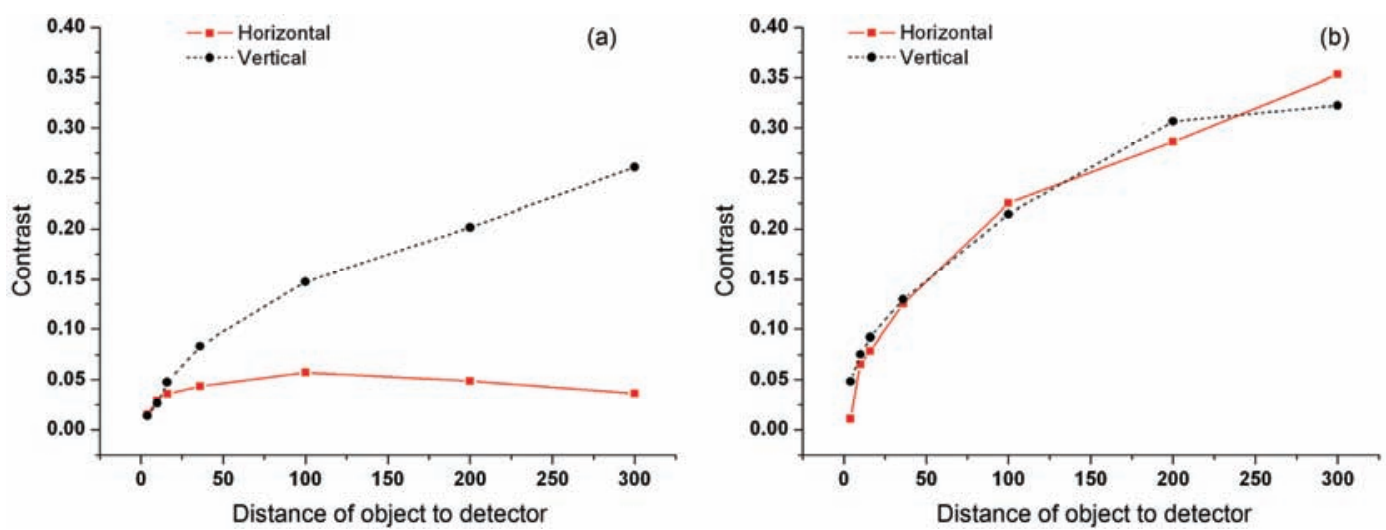

图 5 (网络版彩色)不同光源对称度下细丝样品成像衬度和物像距离的关系曲线. (a) 白光光阑正常打开光源对称度较低时的结果; (b) 白光光 阑关小到约 $210 \mu \mathrm{m} \times 210 \mu \mathrm{m}$, 光源对称度较高时的结果

Figure 5 (Color online) Variation of fiber edge contrast as a function of DOD under two kinds of source symmetry conditions. (a) Results under white beam slit completely opening and low source symmetry conditions; (b) results under $210 \mu \mathrm{m} \times 210 \mu \mathrm{m}$ white beam slit size and high source symmetry conditions 

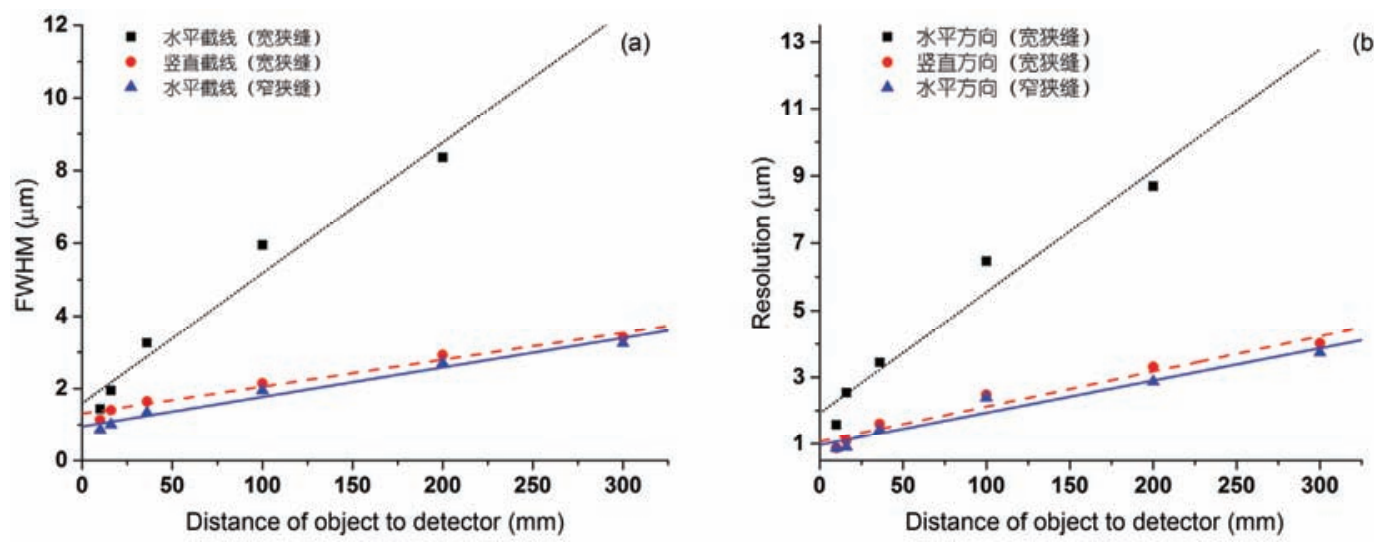

(b)

图 6 (网络版彩色)不同光源对称度的条件下, 细丝边界光强截线的半高全宽(FWHM)(a)和空间分辨率随物像距离的变化(b)

Figure 6 (Color online) (a) Full width at half maximum (FWHM) of intensity curve of pixel line crossing fiber edge and (b) spacial resolution as a function of DOD under different source symmetry conditions

在光源点扩展函数较大的水平方向, 空间分辨率随 物像距离增加快速单调变差, 而在采用光阑约束后 的高对称性等效光源照射下, 水平方向的空间分辨率 得到了明显改善, 并达到了与坚直方向相当的水平.

FWHM随物像距离线性增加的原因是同轴相衬 成像中菲涅耳干涉展宽与光源点扩展函数展宽的共 同作用. 假设光源各点造成的样品边界的展宽相同, 则总展宽是菲涅耳干涉展宽与点扩展函数的卷积. 在本文的物像距离范围内, 菲涅耳干涉展宽较小, 上 述展宽主要来自光源的点扩展函数, 其斜率与光源 尺寸成正比关系. 因此, 对高对称度光源 (光阑关小 的情况下), 可以获得非常对称的空间分辨率和相位 衬度.

虽然光源尺寸大的方向不太影响光源尺寸小的 方向的成像衬度和分辨率, 但是由于实际样品结构 的取向复杂, 相位衬度和空间分辨率互相干扰, 图像 的整体质量会严重下降, 难以突破光源尺寸大的方 向限制的相位衬度和分辨率水平. 随着光源对称度 的提高, 同轴相衬成像的衬度和空间分辨率的对称 性也大大提高, 从而大幅提高成像的质量.

\section{4 关于最佳成像条件的讨论}

人们总是希望获得的图像既有高空间分辨率, 又有强衬度, 两者可以兼得的成像一直是成像研究 的重要目标. 可以注意到, 在本实验涉及的物像距离 (4 300 mm) 范围内, 光阑完全打开条件下, 水平方向 的相位衬度在 $100 \mathrm{~mm}$ 附近达到了极大值, 之后随着 物像距离增加, 衬度反而逐渐下降; 其他条件下的相
位衬度则随着物像距离增加而不断增大. 相位衬度 不会无限制地提高, 在本实验的物像距离内, 大部分 实验条件下还没有达到衬度最大的物像距离. 衬度 极大位置与光源对称性、X射线能量、样品的材质和 尺寸、探测器分辨率和灵敏度等多种因素相关, 这将 是本研究下一步工作的方向. 同时, 由于空间分辨率 随着物像距离的增加而下降，如何在空间分辨率和 相位衬度这两个因素间取得平衡来定义最佳成像条 件也有待进一步研究和探讨.

\section{3 讨论和展望}

光源点扩展函数的大小不仅决定成像的空间分 辨率, 在相位衬度成像时, 更显著决定着物体相位衬 度的大小. 通过减小光源的点扩展函数, 可以大幅提 高成像的相位衬度水平, 这种提高对采用高能 $\mathrm{X}$ 射线 开展同轴相衬成像时非常重要, 此时成像衬度不够 高是最主要矛盾.

此外, 高对称度的小尺寸X射线源不仅使同轴相 位衬度成像整体图像的空间分辨率趋于一致, 而且 使整体图像的相位衬度水平趋于一致. 这两重因素 对称性的提高, 大大提升了同轴相位衬度成像的质 量, 这一点将为发展更高水平的相衬成像技术指明 方向.

目前, 所有同步辐射光源的电子束团都是水平 方向尺寸远大于垂直方向尺寸的低对称度光源，只 能通过在光束线上利用减小水平方向的光阑来获得 对称度较高的光源. 由于电子束团的垂直尺寸为 100 $\mu \mathrm{m}$ 量级(第二代光源)到 $10 \mu \mathrm{m}$ 量级(第三代光源), 水 
平光阑的开口尺寸要小于这个尺寸才能获得对称光 源, 而且光阑的位置离光源越远, 需要光阑的开口尺 寸越小. 这个光阑大大减小了束线的光斑尺寸和总 光子通量. 正在设计中的新一代光源将采纳圆形电 子束光源, 如APS-II和HEPS, 将使同步辐射光源的 优势在同轴相位衬度成像中得到真正有效发挥.
总之，采用高对称度光源，将使得所有提升空间 分辨能力和相位衬度水平的努力, 都会带来相应的 图像质量的提升，从而使高分辨相位衬度成像成为 可能. 如果能进一步提升探测器的空间分辨能力, 梦 想中的活体、动态、实时、细胞水平的相位衬度成像 亦将成为可能.

对Massachusetts General Hospital和Harvard Medical School的Gupita教授及上海科技大学的江怀东教授的建设性 讨论, 中国科学院高能物理研究所加速器中心的岳军会博士和祝德充博士在BSRF 4 W1束流尺寸方面的讨论和 协助，北京同步辐射装置 $4 \mathrm{~W} 1 \mathrm{~A}$ 成像站在束线机时上的协助，在此一并致谢.

\section{参考文献}

1 Snigirev A, Snigireva I, Kohn V, et al. On the possibilities of X-ray phase contrast microimaging by coherent high-energy synchrotron radiation. Rev Sci Instrum, 1995, 66: 5486-5492

2 Chapman D, Thomlinson W, Johnston R E, et al. Diffraction enhanced X-ray imaging. Phys Med Biol, 1997, 42: 2015-2025

3 David C, Nöhammer B, Solak H H, et al. Differential X-ray phase contrast imaging using a shearing interferometer. Appl Phys Lett, 2002, 81: 3287-3289

4 Wilkins S W, Gureyev T E, Gao D, et al. Phase-contrast imaging using polychromatic hard X-rays. Nature, 1996, 384: 335-338

5 Cloetens P, Ludwig W, Baruchel J, et al. Holotomography: Quantitative phase tomography with micrometer resolution using hard synchrotron radiation X rays. Appl Phys Lett, 1999, 75: 2912-2914

6 Pagot E, Fiedler S, Cloetens P, et al. Quantitative comparison between two phase contrast techniques: Diffraction enhanced imaging and phase propagation imaging. Phys Med Biol, 2005, 50: 709-724

7 Gureyev T E, Mayo S, Wilkins S W, et al. Quantitative In-line phase-contrast imaging with multienergy X rays. Phys Rev Lett, 2001, 86: $5827-5830$

8 Baruchel J, Cloetens P, Härtwig J, et al. Phase imaging using highly coherent X-rays: Radiography, tomography, diffraction topography. J Synchrotron Rad, 2000, 7: 196-201

9 Nugent K A, Gureyev T E, Cookson D F, et al. Quantitative phase imaging using hard X rays. Phys Rev Lett, 1996, 77: 2961-2964

10 Pogany A, Gao G, Wilkins S W. Contrast and resolution in imaging with a microfocus X-ray source. Rev Sci Instrum, 1997, 68: $2774-2782$

11 Jia Q J, Chen Y, Li G, et al. Optimization of the in-line X-ray phase-contrast imaging setup considering edge-contrast enhancement and spatial resolution. Chin Phys C, 2012, 36: 267-274

12 Jiang J H, Zhao J Y, Tian Y L, et al. The X-ray topography station at the Beijing synchrotron radiation facility. Nucl Instr Meth Phys Res A, 1993, 336: 354-360

13 Born M, Worf E. Principles of Optics (in Chinese). 7th ed. Beijing: Publishing House of Electronics Industry, 2009. 249 [Born M, Worf E. 光学原理. 第七版. 北京: 电子工业出版社, 2009. 249] 


\title{
Synchrotron radiation X-ray in-line phase-contrast imaging with highly symmetric source
}

\author{
LI Gang $^{1 * \dagger}$, ZHANG Jie $^{1 \dagger}$, YI QiRu ${ }^{1 \dagger}$, WANG YanPing ${ }^{1}$, CHEN Yu $^{1}$, JIA QuanJie $^{1} \&$ \\ JIANG XiaoMing ${ }^{1,2 * \dagger}$ \\ ${ }^{1}$ Institute of High Energy Physics, Chinese Academy of Sciences, Beijing 100049, China; \\ ${ }^{2}$ Beijing Advanced Sciences and Innovation Center of Chinese Academy of Sciences, Beijing 101407, China \\ *Corresponding authors, E-mail: lig@ihep.ac.cn; jiangxm@ihep.ac.cn \\ $\dagger$ Equally contributed to this work
}

In available synchrotron radiation facilities all over the world, the size of electron beam bunch has distinct difference between the horizontal direction and the vertical direction at the cross section vertical to electron moving direction. It will cause low symmetry of source size in horizontal and vertical directions, and result in big difference in the spacial resolution and phase contrast between these two directions in synchrotron radiation X-ray in-line phase contrast imaging. The superior resolution and phase contrast of one direction will couple with the inferior ones of the other direction in actual object imaging, this interaction will degrade both spacial resolution and phase contrast of the whole image and lead to poor image quality. In this paper, a four-knife white beam slit is used in Beijing synchrotron radiation facility (BSRF) 4W1A beamline to adjust source size in horizontal and vertical directions and restrict the point spread function (PSF) of source, the source size is limited from $1.23 \mathrm{~mm}$ (horizontal) $\times 0.46 \mathrm{~mm}$ (vertical) to $0.35 \mathrm{~mm} \times 0.35 \mathrm{~mm}$. By this way, a highly symmetric effective X-ray source is obtained. The symmetry of source size is improved from 2.7 to about 1. Although the total X-ray flux loses $99.95 \%$, the X-ray flux density is only reduced to $22 \%$. It because total flux is taken account of the expanded spot size due to divergence, while flux density is mainly related to effective source size, which is limited not severely as expanded spot size by white beam slit. The flux density reduction by this method is not a critical defect in high resolution X-ray phase contrast imaging and can be improved by other ways. The polyamide fiber net is imaged using X-ray in-line phase contrast imaging at 4W1A, BSRF. Diameter of fiber is about 50 microns, X-ray energy is $13 \mathrm{keV}$, the effective pixel size is 0.325 micron, the experiment images are obtained at object-to-detector distances of 4 , $10,16,36,100,200$ and $300 \mathrm{~mm}$ with source-to-object distance of about $43 \mathrm{~m}$. The results show that when source size in horizontal direction is limited from 1.23 to $0.35 \mathrm{~mm}$ (symmetry of source size is about 1 at this condition), the maximal phase contrast of image is advanced from 0.057 to 0.35 . It means the density sensitivity is promoted about 5 times than in ordinary source size conditions. The spacial resolutions in different source size symmetry conditions are also primary analyzed based on Rayleigh criterion. The result shows that spacial resolution can be improved notably in horizontal direction by limiting horizontal source size to a nearly symmetric source size condition. Our work demonstrates that the spacial resolution and phase contrast can be promoted at the same level by source size symmetry improved, which markedly improved the imaging quality in synchrotron radiation X-ray in-line phase-contrast imaging. It will have great benefit to high-resolution X-ray in-line phase contrast imaging. The reasons of these improvements are analyzed and developments in future are also discussed.

X-ray in-line phase-contrast imaging, source symmetry, contrast, spacial resolution, synchrotron radiation, point spread function

doi: 10.1360/N972016-00905 